\title{
INTRODUCTION TO HEALTH AND SAFETY RESPONSIBILITIES
}

\author{
G.W. Norval \\ Department of Chemical Engineering and Applied Chemistry \\ University of Toronto \\ 200 College St. \\ Toronto, Ontario, M5S 3E5 \\ Graeme.norval@utoronto.ca
}

\begin{abstract}
The accreditation requirement is that all engineering students be introduced to their professional responsibilities, and particularly, those relating to "social, health, safety and legal" aspects. There is no definition as to what this entails, and there are considerable differences between schools in delivered content.
\end{abstract}

Ontario has made two substantial changes to Health and Safety legislation and regulation. Workers, supervisors and employers have always been covered by the legislation; the legislative changes mean that students are now covered under Occupational Health and Safety legislation. This change brings all undergraduate teaching facilities into compliance with the Industrial Regulations. The impact on research will be profound as all research laboratories will workplaces, under the Industrial Regulations, and supervisors will have "supervisory" obligations for their students.

Ontario now requires that all workers have introductory training on the health and safety system as well as training on workplace specific hazards. All supervisors are required to complete training on their responsibilities, including hazard recognition. This training is available as e-modules, and this minimum training is acceptable for all workplaces, and workplaces are allowed to use their own materials so long as they cover a defined list of topics. The supervisory level material defines a minimum standard of content for all engineers, which is readily supplemented by additional content, such as working at heights, WHMIS, and electrical safety.

Keywords: Health and Safety; WHMIS, Professionalism
The practice of engineering is a regulated profession. In Canada, the provinces are responsible for regulating the profession, and professionals need to be licensed in the jurisdiction in which they work.

Engineering in Ontario is defined as follows: "practice of professional engineering" means any act of planning, designing, composing, evaluating, advising, reporting, directing or supervising that requires the application of engineering principles and concerns the safeguarding of life, health, property, economic interests, the public welfare or the environment, or the managing of any such act;" [1]. An engineer's primary duty is to the public and not the employer and not to the client.

A different way to say this is that when an engineer makes a mistake, the consequences can be enormous. The famous examples include the Challenger and Columbia, and Columbia is more troubling because not all of the lessons learned from Challenger were learned. There are Bhopal, Seveso and more recently West, Texas and Lac Megantic. Montréal is dealing with le Pont Champlain, and Toronto has the Gardiner Expressway, and aging infrastructure, and there is the Elliot Lake mall collapse. At the heart of all of these high profile issues is the balance of business and engineering decisions - or ethics and judgment.

The Accreditation requirements specifically mention safety in regards to the attributes of Design, as well as with regards to the Impact of engineering on society and the environment. Thereafter, safety is mentioned in regards to Laboratory Experience and Safety Procedures instruction. [2] No guidance is provided on what this is to entail. This submission begins to define a minimum standard against which the accreditation requirements can be judged.

\section{LEGISLATIVE BACKGROUND}

\section{INTRODUCTION}


In Ontario Occupational health and safety legislation was introduced in 1978, following from the Ham Commission on the health and safety of workers in mines. [3, 4] The act covered all workers (under provincial jurisdiction), with workers defined as a person who performs work or supplied a service for monetary compensation.

This created an intriguing issue in the education profession. Schools, colleges and universities are all workplaces under the law. Faculty and teaching assistants are all workers under the law. However, students are not workers, under the law. The protection due to students falls to the duty of care provisions of common law.

The same is true for recreational facilities. The workers are covered by health and safety legislation, and the patrons are not.

In the event of a critical injury or fatality of a worker in a workplace, the Ministry of Labour must be contacted and the Ministry must investigation. The scene must be protected from change until released by the Ministry inspectors.

Yet, if a student or patron is injured or killed, the Ministry of Labour is not brought in. Further, an investigation, if any is conducted by the police (a criminal investigation purposes) or the coroner (in cases of fatalities). None of these investigations have the goal of identifying the root causes and of ensuring that changes are instituted in order to prevent a recurrence.

This issue was settled in law in a case involving the Blue Mountain Resorts and the drowning death of a patron in 2007. An inspector originally charged the resort with failure to report the incident. The case was supported by a decision of the Ontario Labour Relations Board. However, it was overturned by the Ontario Court of Appeal. The Court of Appeal defined the boundary of the Ministry of Labour as to being where there is some "reasonable nexus between the hazard giving rise to the death or critical injury and a realistic risk to workers' safety at the workplace". [5]

\section{IMPACT ON EDUCATION}

On May 26, 2011, a student was killed in a shop incident at an Ottawa area high school. On August 16, 2012, the Ottawa Catholic District School Board pleaded guilty to various charges under the Occupational Health and safety Act. Specifically, to failing, as an employer, to provide information, instruction and supervision to the teacher concerning safe work practices and recognition of the hazards associated with the class project. [6]
This case is similar to one underway in California. On December 29, 2008, a recent chemistry graduate, then employed as a Research Assistant, was fatally burned in a laboratory incident. The University of California was charged by the California Division of Occupational Health and safety, and settled the case out of court, in an agreement that dropped the felony charges against the university. The felony charges against the chemist's supervisor are being tried in court. [7] This is the first North American case of a university supervisor being charged followed a laboratory incident. Sussex University was prosecuted by the UK Health and safety Executive (HSE) following an incident in which a piece of metal was shot into a student's abdomen. [8]

Subsequent to the settlement of the Ottawa case, the Ontario Ministry of Labour, and the Ontario Ministry of Education agreed that in the Ministry of Labour inspectors were to be notified following of all critical injuries and fatalities of student in which the same hazard could have impacted an employee. The same arrangement exists with the Ministry of Training, Colleges and Universities, and impacts all universities in the province.

Of more importance is the change in the definition of "worker" under the Occupational Health and Safety Act. The new definition is: "worker" means any of the following, but does not include an inmate of a correctional institution or like institution or facility who participates inside the institution or facility in a work project or rehabilitation program:

1. A person who performs work or supplies services for monetary compensation.

2. A secondary school student who performs work or supplies services for no monetary compensation under a work experience program authorized by the school board that operates the school in which the student is enrolled.

3. A person who performs work or supplies services for no monetary compensation under a program approved by a college of applied arts and technology, university or other post-secondary institution.

4. A person who receives training from an employer, but who, under the Employment Standards Act, 2000, is not an employee for the purposes of that Act because the conditions set out in subsection 1 (2) of that Act have been met.

5. Such other persons as may be prescribed who perform work or supply services to an employer for no monetary compensation; ("travailleur"). [9]

It is a fair comment to suggest that there were several drivers for the change in the definition. High school students are required to complete a volunteer position prior to graduation, and this change makes it evident, in law, that organizations which use the services of 
volunteers are responsible for the safety of those volunteers, and that the standard is the same as that for employees. The change also is part of the larger issue of addressing "internships", and ensuring that employers are responsible for ensuing the safety of "intern", and to the same standard as employees.

The revised definition has the impact of defining students as having the same rights (and responsibilities) as workers. It is evident that all research studies (graduate and undergraduate) meet the definition. Further, if the student is performing research in a different country or province, the Ontario standard will apply to students from an Ontario university.

The various legal issues are converging to the place whereby all student activities must be considered as if an Employer-Employee (archaically called a Master-Servant) relationship exists between the parties. The civil law duty of care principle exists, and that it has been codified in the law.

\section{CRIMINAL CODE}

While the discussion refers to Ontario provincial law, it is important to consider S217.1 of the Criminal Code of Canada. [10] The text states that "Every one who undertakes, or has the authority, to direct how another person does work or performs a task is under a legal duty to take reasonable steps to prevent bodily harm to that person, or any other person, arising from that work or task."

This clause has been tested in court, and the courts have passed judgement on its constitutionality. The clauses are one of the outcomes of the Westray explosion. [11]

\section{AN ENGINEERING EDUCATION}

There is no agreed definition of the required content for legislation, codes and standards as well as health and safety for an engineering education. In the absence of a standard, engineering educators are able to create their own. And, there are very good starting points.

In Ontario, all workers must receive a basic training in health and safety. The content has been defined as:

- Rights and responsibilities of worker and supervisors, under the Occupational Health and Safety Act

- Roles of workplace parties, health and safety representatives, and joint health and safety committees

- Roles of the Ministry of Labour, Workplace Safety and Insurance Board, and health and safety partners, including WSPS

as well as to receive instruction on

- Hazard recognition
- Right to be informed of hazards

- Reference to an employer's obligations to provide information and instruction to workers about controlled products

- Latency and illness related to occupational disease

Given that all students will become workers at some time, this seems a reasonable place to start. The Ontario Ministry of Labour has developed guidebooks, in multiple languages, which are available in both printed and pdf format. Further, there is an on-line course with its own test. [13] The students can be required to complete the course, and to provide an electronic copy of their certificate as proof of completion, as part of the "notclosely supervised" portion of a first year course.

There is a higher level of training available for supervisors, again both as printed and pdf versions in multiple languages, with an e-course with a test. The supervisor level has additional material that covers the supervisors' responsibilities for Hazard Recognition, Hazard Assessment, Hazard Control. [14] This component could be included in an upper year design course, and clearly would be a requirement of any entrepreneurship course.

The advantage of using the Ministry of Labour material is that standard of the training is defined by the Ministry of Labour. Getting all engineering students to this level will be a major accomplishment.

Further, there is the ability to bring aspects of the Canadian law and Canadian cases into the Introductory Engineering courses. The Westray explosion is well documented. The Metron case involves the deaths of 4 workers following the collapse of a swingstage; all were wearing fall arrests, none of which were tied off. The Elliot Lake roof collapse is a third example of the Duty of Care. This material can be covered as case studies.

\section{SUMMARY}

The changes in the legislative requirements on health and safety have been presented. An initial definition of the minimum standard for an engineering education has been presented. Simple, and freely available tools have been presented and discussed.

In particular, the role of supervisors, and in particular the role of research supervisors will change. It will no longer be acceptable for research supervisors to be ignorant of the daily practices in their laboratories.

\section{REFERENCES}


[1] Professional Engineers Act, 1990, R.S.O. Chapter P.28, Government of Ontario, (last amendment 2010).

[2] 2013 Accreditation Criteria and Procedures, Canadian Engineering Accreditation Board, Engineers Canada, Ottawa, Ontario, 2013.

[3] Occupational Health and Safety Act, 1990, R.S.O., Chapter O.1, Government of Ontario, (last amendment 2011).

[4] Ham, J.M., "Report of the Royal Commission on the Health and Safety of Workers in Mines", Government of Ontario, 1976.

[5] Keith, N., "Blue Mountain Resorts wins at the Court of Appeal: Judgement leaves some confusion for employers", OHSLaw Report, March 2013.

[6] "Ottawa Catholic School Board Fined \$275,000 After Classroom Explosion”, Government of Ontario News Release, August 16, 2012.

[7] “California Deal Tightens Lab Safety”, C.\& En News 90 (33) 34-37 (2012).

[8] van Noorden, R., " Fatality adds further momentum to calls for a shake-up in academic safety culture", Nature 472 270-272 (2011).

[9] Bill 146, "Stronger Workplaces for a Stronger Economy Act, December 4, 2013.

[10] Criminal Code, R.S.C., S217.1 1985, Government of Canada (last amendment 2013)

[12] Richard, K. P. "The Westray Story: Report of the Westray Mine Public Inquiry” Government of Nova Scotia (1997).

[13]

http://www.labour.gov.on.ca/english/hs/training/workers.php

[14]

http://www.labour.gov.on.ca/english/hs/training/supervisors.php 